\title{
MODEL PENALARAN PENULISAN ARTIKEL ILMIAH MAHASISWA PROGRAM STUDI PBSI FBS UNY
}

\author{
Ary Kristiyani \\ Fakultas Bahasa dan Seni Universitas Negeri Yogyakarta \\ email: ary kris@yahoo.com
}

\begin{abstract}
ABSTRAK
Penelitian ini bertujuan untuk mendeskripsikan model penalaran penulisan artikel ilmiah mahasiswa Program Studi Pendidikan Bahasa dan Sastra Indonesia, Fakultas Bahasa dan Seni, Universitas Negeri Yogyakarta. Penelitian ini menggunakan desain penelitian analisis konten dengan menggunakan pendekatan kualitatif. Desain ini untuk membuat estimasi beberapa gejala dalam konteks data. Desain tersebut digunakan jika analisis konten merupakan satu-satunya teknik yang digunakan. Penelitian ini menemukan berbagai model penalaran penulisan artikel ilmiah mahasiswa Program Studi PBSI, FBS, UNY. Model penalaran penulisan artikel ilmiah dapat diklasifikasikan berdasarkan arah atau alur penalaran yakni penalaran deduktif dan penalaran induktif. Model penalaran deduktif bersifat dominan, artinya di setiap artikel ilmiah mahasiswa terdapat model penalaran tersebut, bahkan model tersebut beberapa kali muncul pada setiap artikel ilmiah mahasiswa. Model penalaran juga dapat diklasifikasikan berdasarkan urutan pengembangan paragraf. Temuan dalam penelitian ini antara lain model urutan waktu atau kronologis dan model urutan kepentingan.
\end{abstract}

Kata kunci: Model penalaran, artikel ilmiah.

\section{THE REASONING MODELS OF WRITING SCIENTIFIC ARTICLES OF THE STUDENTS IN INDONESIAN LANGUAGE AND LITERATURE EDUCATION STUDY PROGRAM, FACULTY OF LANGUAGES AND ARTS, YOGYAKARTA STATE UNIVERSITY}

\begin{abstract}
This research aims to describe reasoning models of writing scientific articles of the students in Indonesian Language and Literature Education Study Program, Faculty of Languages and Arts, Yogyakarta State University. This research employed content analysis design and a qualitative approach. The design was used to make estimatesof severaltendencies in the data context. The design was used if content analysis was the only technique employed. The result of this research shows several models of reasoning in writing scientific articles. The models can be classified based on direction or reasoning patterns, i.e. deductive and inductive reasoning. The deductive reasoning model is dominant, meaning that in every student's scientific article the model exists, even for several times. The reasoning models can also be classified based on the order of paragraph development, i.e. the models of time or chronological order and significance order.
\end{abstract}

Keywords: reasoning models, scientific articles

\section{A. PENDAHULUAN}

Mahasiswa sebagai generasi penerus estafet kepemimpinan harus mampu memiliki keterampilan menulis karya ilmiah. Dalam hal ini, mahasiswa Jurusan Pendidikan Bahasa dan Sastra Indonesia dibekali keterampilan menulis karya ilmiah yang terwujud dalam mata kuliah wajib ditempuh. Mata kuliah ini membekali mahasiswa untuk memiliki keterampilan menulis ilmiah, seperti esai, artikel ilmiah, makalah, proposal penelitian, dan skripsi. 
Menulis artikel ilmiah sebagai salah satu bentuk karya ilmiah merupakan tulisan tentang suatu masalah yang memiliki unsur keilmiahan. Mahasiswa harus mampu menuangkan pemikiran, ide, gagasan yang disusun dengan sistematika keilmiahan dan diharapkan hasil karyanya dapat dipublikasikan. Penyampaian gagasan dalam artikel ilmiah memiliki berbagai model penalaran. Model penalaran menulis karya ilmiah sangat penting bagi setiap penulis karena dapat menuangkan gagasaannya melalui penalaran yang mudah dipahami oleh pembaca.

Berdasarkan pemikiran tersebut, perlu dikaji model-model penalaran menulis artikel ilmiah mahasiswa Program Studi Pendidikan Bahasa dan Sastra Indonesia. Temuan berbagai model penalaran mahasiswa dalam menulis artikel ilmiah, nantinya dapat digunakan sebagai panduan bagi dosen untuk memberikan bimbingan dan pengarahan dalam menyusun tugas akhir skripsi. Dengan demikian, proses penulisan skripsi diharapkan tidak menemui kendala yang berarti sehingga dapat mempercepat penyelesaian tugas akhir atau skripsi mahasiswa.

Artikel dalam konteks penulisan merujuk pada tulisan ilmiah yang dipublikasikan dalam jurnal ilmiah. Artikel ilmiah dibedakan menjadi dua, yakni: (1) artikel hasil penelitian dan (2) artikel nonpenelitian berisi hasil pemikiran atau hasil kajian pustaka (Budiharso, 2009: 76-77). Lebih lanjut dikatakan, artikel hasil penelitian diangkat dari laporan penelitian sebelumnya ditulis dalam beberapa bab. Adapun artikel hasil pemikiran merupakan gagasan ilmiah dari penulis yang dituangkan dengan merujuk pada teori tertentu. Artikel nonpenelitian dapat digali berdasarkan kajian bukubuku teks atau hasil penelitian yang dirangkai menjadi gagasan tersendiri.

Menurut Budiharso (2009: 77) artikel hasil penelitian memiliki dua ciri. Pertama, artikel mengutamakan penyajian temuan penelitian, pembahasan, dan simpulan secara ringkas, sistematis, dan tajam. Kedua, kajian pustaka ditulis secara ringkas dan padat dalam latar belakang masalah. Kajian pustaka untuk artikel hasil penelitian berfungsi sebagai latar belakang masalah, untuk mengawali artikel, menjelaskan rasional penelitian, dan penegasan mengenai rumusan masalah dan tujuan penelitian.

Artikel hasil pemikiran atau kajian pustaka merupakan pemikiran penulis tentang suatu permasalahan. Artikel hasil pemikiran haruslah bersifat provokatif, merangsang pembaca untuk mengkaji isi artikel (Budhiharso, 2009: 77-78). Lebih lanjut dikatakan, artikel hasil pemikiran dikembangkan berdasarkan tulisan dalam artikel yang relevan, hasil-hasil penelitian terdahulu, dan buku teks. Unsur terpenting dari artikel hasil pemikiran adalah pendapat penulis tentang suatu masalah yang dibahas. Penulis menunjukkan hasil pemikiran kritis dan analitis terhadap suatu permasalahan. Jadi, artikel hasil pemikiran bukan sekedar tempelan pemikiran orang lain yang dikutip dalam artikel lain. Artikel hasil pemikiran biasanya disajikan dalam format: judul, nama penulis, abstrak, kata kunci, pendahuluan, bagian inti atau pembahasan, penutup, dan daftar pustaka. Dalam penelitian ini, artikel yang diteliti adalah artikel ilmiah hasil pemikiran. Mahasiswa berpikir kritis dan analitis terhadap persoalan yang dikemukakan. Tulisan yang baik, harus memperhatikan beberapa unsur. Unsur-unsur tersebut di antaranya, sintaksis (kalimat), gramatika, mekanik, isi, proses menulis, pengetahuan mengenai pembaca, tujuan penulisan, penggunaan pilihan kata, dan organisasi tulisan.

Rahardi (2009: 161-162) mengurai beberapa model berpikir atau penalaran penulisan karya ilmiah yang lazim digunakan sebagai berikut.

1. Model DAM-D: duduk perkara, alasan, misal, duduk perkara

Model ini, uraian dimaksudkan untuk menjelaskan duduk perkara persoalan. Uraian duduk perkara persoalan harus didukung oleh alasan-alasan yang kuat. Setelah disampaikan alasan-alasan, segera disusul dengan contoh-contoh yang tepat. Langkah terakhir, menjelaskan kembali duduk perkara persoalan itu agar menjadi jelas.

2. Model DSD: dahulu, sekarang, depan Sebuah topik diolah dengan memaparkan bagaimana hal itu diterima, ditanggapi, dipahami, ditaati, dicermati, pada masa lampau, masa kini, dan masa yang akan datang. 
3. Model PMHT: perhatian, minat, hasrat, tindakan

Model ini tepat digunakan untuk mengorbankan semangat, membangkitkan minat, mengobarkan hasrat, dan yang terakhir membangkitkan tindakan tertentu.

4. Model 5 W 1 H: what, who, when, where, why, how

Model pemaparan ini lazim digunakan dalam surat kabar, terutama untuk menulis berita-berita yang lugas (hard news), sekalipun sekarang kecenderungan penulisan berita sudah bergeser ke model penulisan feature (karkhas). Hampir semua feature menggunakan model tulisan ekspositoris dan naratif.

5. Model TAS: tesis, antitesis, sintesis

Model ini, persoalan dikaji dari dimensi kontras atau berlawanan: kebaikan-keburukan, keuntungan-kerugian, keunggulan-kelemahan. Kemudian, penulis melanjutkannya dengan membuat sintesis atau perpaduan untuk meragkum tesis dan antitesis itu.

6. Model PIK: pendahuluan, isi, kesimpulan

Model ini, penulis menggawali uraiannya dengan memaparkan pendahuluan yang menarik, jelas, mampu membawa ke dalam persoalan pokoknya. Selanjutnya dalam bagian isi, penulis mencurahkan segalanya secara total untuk mengontraskan, membandingkan, menguraikan, memaparkan, mengintepretasi persoalan yang sedang dikaji. Akhirnya, ditutup dengan kesimpulan.

Budiharso $(2009 ; 27)$ mengemukakan ada 2 jenis teknik penalaran dalam tulisan argumentasi, yakni: pertama, teknik induktif adalah bernalar untuk melihat apakah dari contoh-contoh yang ada dapat ditarik suatu kesimpulan umum yang dapat diterima akal. Kedua, teknik deduktif adalah penalaran yang dimulai dengan pengutaraan pernyataan umum untuk melihat apakah pernyataan umum dapat dibuktikan dengan contoh-contoh kasus.

Selain model penalaran di atas, Rahardi (2009: 172-173) juga mengemukakan tentang pola pengembangan paragraf, di antaranya: (1) pola runtun ruang dan waktu, (2) pola sebabakibat, (3) pola susunan pembanding, (4) pola susunan ibarat, (5) pola susunan daftar, (6) pola susunan contoh, dan (7) pola susunan bergambar. Berikut akan disajikan lebih lanjut tentang 7 pola pengembangan paragraf.

\section{Pola runtutan ruang dan waktu}

Pola ini biasanya digunakan untuk menggambarkan suatu kejadian dan peristiwa atau cara membuat sesuatu, selangkah demi selangkah yang digambarkan menurut perturutan ruang dan waktu.

\section{Pola sebab-akibat}

Pola ini biasanya digunakan dalam karangan ilmiah untuk mengemukakan alasan tertentu terkait justifikasi, menerangkan alasan terjadinya sesuatu, menjelaskan sesuatu proses yang berpautan dengan sebab dan akibat dari terjadinya hal-hal tertentu.

\section{Pola susunan pembanding}

Pola pembanding ini digunakan untuk membandingkan dua hal atau dua perkara, bahkan dapat juga lebih, yang di satu sisi memiliki kesamaan sedangkan pada sisi lain mengandung perbedaan.

\section{Pola susunan ibarat}

Pola ini digunakan untuk menjelasakan sesuatu hal yang memiliki keserupaan atau kemiripan dengan hal tertentu. Jenis paragraf ini, sering digunakan bentuk-bantuk peribaratan, personifikasi, metafora, dan lain-lain.

\section{Pola susunan daftar}

Pola ini lazimnya digunakan dalam karyakarya ilmiah yang mengemukakan informasi dalam bentuk daftar, tabel, grafik, dan semacamnya.

\section{Pola susunan contoh}

Susunan paragraf ini, kalimat rinciannya lazim menggunakan contoh-contoh tentang apa yang dimaksudkan dalam kalimat topik atau kalimat utama. Pola susunan contoh juga banyak sekali ditemukan dalam tulisantulisan ilmiah.

\section{Pola susunan bergambar}

Gambar atau ilustrasi tertentu dimaksudkan untuk memperjelas apa yang telah atau akan dituliskan di dalam sebuah paragraf. Pola susunan bergambar sangat lazim ditemukan dalam karya ilmiah.

Model penalaran penulisan terkait dengan pola pengembangan paragaf. Jadi, perlu di- 
pahami bagaimana pola penulis dalam mengembangkan paragraf. Pemilihan pola pengembangan paragraf yang tepat dalam penulisan karangan ilmiah dapat membantu pembaca memahami model penalaran penulis.

Senada dengan pendapat di atas, Akhadiah, Arsjad, dan Ridwan (1996: 41-43) membagi penalaran dalam karangan menjadi 2, yakni: penalaran induktif dan penalaran deduktif. Penalaran induktif adalah proses penalaran untuk menarik kesimpulan berupa prinsip atau sikap yang berlaku umum berdasarkan atas faktafakta yang bersifat khusus, prosesnya disebut induksi. Adapun penalaran induktif dapat berupa generalisasi, analogi, atau hubungan sebab akibat. Generalisasi adalah proses penalaran berdasarkan pengamatan atas sejumlah gejala dengan sifat-sifat tertentu mengenai semua atau sebagian dari gejala serupa itu. Di dalam analogi, kesimpulan tentang suatu gejala ditarik berdasarkan pengamatan sejumlah gejala khusus yang bersamaan. Hubungan sebab akibat ialah hubungan ketergantungan antara gejala-gejala yang mengikuti pola sebab akibat, akibat-sebab, dan akibat-akibat.

Penalaran deduktif dimulai dengan suatu pernyataan atau umum berupa kaidah, peraturan, teori, atau pernyataan umum. Selanjutnya, pernyataan itu akan dikembangkan dengan pernyataan-pernyataan atau rincian-rincian yang bersifat khusus. Proses penulisan tidak dapat dipisahkan dengan pemikiran atau penalaran. Tulisan adalah perwujudan hasil pemikiran atau penalaran. Tulisan yang kacau mencerminkan pemikiran yang kacau. Oleh karena itu, latihan keterampilan menulis pada hakikatnya adalah pembiasaan berpikir atau bernalar secara tertib dalam bahasa yang tertib pula.
Dapat disimpulkan bahwa karya ilmiah merupakan sintesis antara proses deduktif dan induktif. Kedua proses tersebut merupakan arah atau alur penalaran. Penalaran tidak dapat dipisahkan dengan urutan pengembangan paragraf dan isi karangan. Urutan pengembangan paragraf menurut Akhadiah, Arsjad, dan Ridwan (1996: 44-54) antara lain: 1) urutan waktu atau kronologis, 2) urutan ruang atau spasial, 3) urutan alur penalaran, dan 4) urutan kepentingan. Adapun isi karangan terkait karya ilmiah membahas fakta meskipun untuk pembahasan diperlukan teori atau pendapat. Hal-hal yang berhubungan dengan fakta dapat dikelompokkan menjadi 7, antara lain: 1) generalisasi dan spesifikasi, 2) klasifikasi, 3) perbandingan dan pertentangan, 4) hubungan sebab akibat, 5) analogi, 6) ramalan, dan 7) gabungan.

Dalam penelitian ini, analisis model penalaran penulisan artikel ilmiah mahasiswa Program Studi Pendidikan Bahasa dan Sastra Indonesia, Fakultas Bahasa dan Seni, Universitas Negeri Yogyakarta berdasarkan teori yang dikemukakan oleh Akhadiah, Arsjad, dan Ridwan. Analisis akan dimulai dari temuan arah atau alur penalaran dan selanjutnya akan dikaitkan dengan urutan pengembangan paragraf dan isi karangan. Ketiga komponen ini saling terkait sehingga perlu dianalisis secara berkelanjutan.

\section{B. Metode Penelitian}

Penelitian ini menggunakan desain penelitian analisis konten dengan menggunakan pendekatan kualitatif. Desain analisis konten yang digunakan adalah untuk estimasi, seperti yang dkemukakan Krippendorff (via Zuchdi, 1993: 24-25). Desain ini untuk membuat estimasi beberapa gejala dalam konteks data. Desain

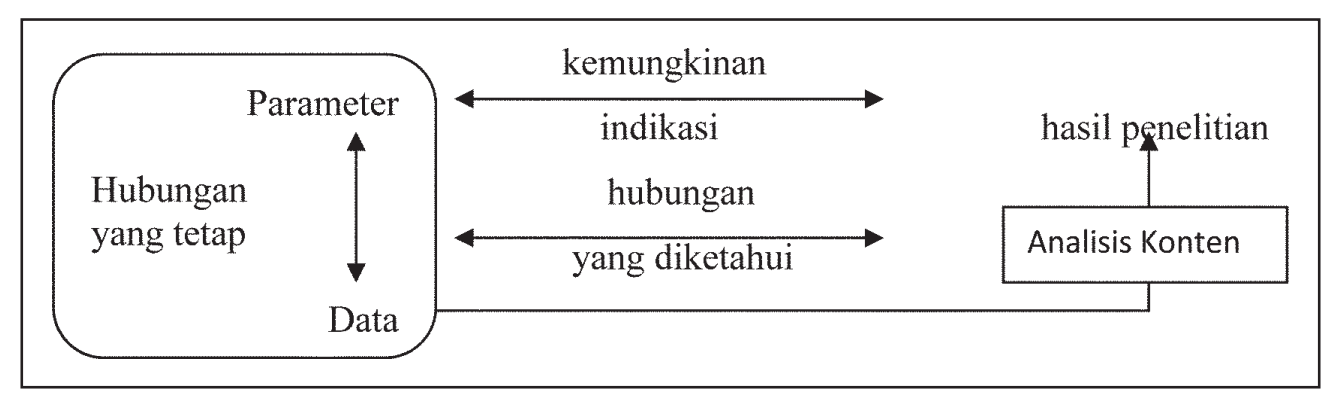

Gambar 1. Desain Analisis Konten untuk estimasi

(Krippendorff via Zuchdi, 1993: 25) 
tersebut digunakan jika nalisis konten merupakan satu-satunya teknik yang digunakan.

Teknik pengumpulan data melalui analisis dokumen. Analisis dokumen dilakukan dengan mengamati dan mempelajari model penalaran mahasiswa dalam menulis artikel ilmiah. Penelitian ini menggunakan teknik analisis deskriptif kualitatif yaitu untuk mendeskripsikan model penalaran mahasiswa dalam menulis artikel ilmiah. Data yang diperoleh dalam penelitian ini diolah dengan menggunakan langkah-langkah kegiatan: (a) reduksi data; (b) penyajian data; dan (c) penyimpulan data.

Aktivitas peneliti bergerak dengan komponen analisis dan pengumpulan data selama proses berlangsung. Kemudian, peneliti bergerak di antara kegiatan reduksi data, penyajian data, dan penarikan kesimpulan. Reduksi data dilakukan dengan mengklasifikasi data yang sejenis dan melakukan kodifikasi. Penyajian data dilakukan dengan mendeskripsikan data yang sudah diklasifikasikan sesuai dengan pokok permasalahan. Penarikan kesimpulan bersamaan reduksi data dan penyajian data. Apabila kesimpulan dipandang belum final, peneliti melakukan pengumpulan data kembali untuk mencari pendukung pembuatan kesimpulan sekaligus pemantapan kembali hal-hal yang ditemukan di lapangan.

Setelah data diperoleh, kemudian direduksi, disajikan, dan disimpulkan. Agar data penelitian terpercaya maka perlu adanya diskusi dengan dosen pembimbing penelitian. Expert Judgment dalam penelitian ini adalah dosen pembimbing yakni Dr. Kastam Syamsi, M.Ed. Adapun untuk mencapai reliabilitas penelitian, yaitu dengan menyajikan data asli seperti hasil pekerjaan mahasiswa yang berupa artikel ilmiah hasil pemikiran.

\section{Hasil dan Pembahasan}

1. Model Penalaran Berdasarkan Arah atau Alur

\section{a. Model Penalaran Deduktif}

Temuan tentang model penalaran berdasarkan arah alur memiliki kencenderungan dominan, artinya setiap tulisan artikel ilmiah mahasiswa terdapat model tersebut yakni penalaran deduksi dan induksi. Penalaran deduktif memiliki intensitas tertinggi dibandingkan dengan induktif. Di setiap tulisan artikel ilmiah mahasiswa terdapat model penalaran deduksi. Temuan model penalaran dalam bentuk paragraf sebagai berikut.

Antologi puisi yang berjudul "Tadarus" ini ditulis oleh Kyai Haji Mustofa Bisri (Gus Mus). Puisi-puisi tersebut menceritakan bagaimana seorang kyai yang memimpin sebuah pondok pesantren melakukan perjalanan spiritual. Tujuannya adalah untuk mencari kebenaran dari firman Alllah dan sabda nabi dengan menempatkaan pertimbangan dalam pilihan perjalanan yang lain. Pilihan itu adalah kehidupan manusia sehari-hari, baik alam semesta, maupun manusianya, bukan kepatuhan dalam melaksanakan misi agama ("Perspektif Strukturalisme Antologi Puisi Tadarus Karya H. Mustofa Bisri: Senandung Tadarus oleh Gus Mus" yang ditulis oleh Rita Mayasari).

Pada bagian tulisan yang lain juga ditemukan model penalaran deduktif seperti pada paragraf berikut ini.

Puisi "Tadarus"adalah puisi utama dalam antologi ini sekaligus menjadi judul antologi tersebut yang ditulis pada tahun $1381 / 1963+1408 / 1988$. Puisi ini berisi tentang gambaran yang diungkapkan perasaan aku lirik (penyair) terhadap manusia yang memaknai ibadah (khususnya bertadarus) hanyalah selingan dari berbagai kesibukan di dunia. Kesibukan yang lain dilakukan di dunia dianggap lebih penting sehingga urusan akhirat (dalam puisi itu disebutkan hari akhir) terabaikan karena menganggap masih banyak waktu sebalum hari itu datang.

Arikel ilmiah yang berjudul "Pentingnya Memilih Media yang Tepat dalam Pembelajaran Bahasa Indonesia" yang ditulis oleh Siti Nurfaizah juga terdapat model penalaran deduktif seperti tampak di bawah ini.

Bahasa Indonesia merupakan salah satu mata pelajaaran yang turut diujikan dalam Ujian Nasional (UN) di Indonesia. Hal tersebut sudah pasti, mengingat bahasa Indonesia adalah bahasa nasional Indonesia. Oleh karena itu, bahasa Indonesia menjadi mata pelajaran wajib bagi seluruh siswa di 
Indonesia. Mata pelajaran ini bertujuan agar siswa mampu menguasai kemampuan berbahasa dan mampu menerapkannya dalam kehidupan sehari-hari pada berbagai bidang keilmuan. Dikarenakan pada umumnya, suatu bidang keilmuan agar dapat dipahami oleh penganutnya, harus menggunakan bahasa yang baik dan benar.

Penalaran deduktif juga terdapat di bagian kajian teori. Media pembelajaran berfungsi sebagai aat bantu dalam pembelajaran yang dapat mempengaruhi lingkungan dan kondisi belajar yang diciptakan oleh guru di kelas. Pemakaian media pembelajaaraan dapat menciptakan minat siswa yang lebih dan memotivasi keinginan belajar siswa.

Kemampuan guru dalam memilih media yang sesuai dan tepat dengan tujuan yang ingin dicapai juga merupakan pertimbangan penting dalam proses pembelajaran. Pemilihan media yang tidak tepat aatau asal pilih dapat mengurangi kemampuan siswa dalam menyerap dan memahami materi atau bahan ajar yang disampaikan oleh guru. Sebab media yang kurang tepat ini dapat sangat berpengaruh terhadap informasi yang diperoleh.

"Inovasi Pembelajaran Bahasa untuk Siswa SMA melalui Pendekatan Konstruktivisme" yang ditulis oleh Uswatun Khasanah juga terdapat penalaran deduktif seperti tampak di bawah ini.

Siswa dipandang sebagai pribadi yang sudah memiliki kemampuan atau pengetahuan awal sebelum mempelajari sesuatu. Siswa terlibat aktif sebagai subjek pembelajaran. Siswa memiliki kebebasan untuk membangun ide atau gagasan pribadi tanpa pengaruh orang lain.

Guru atau pendidik berperan sebagai seorang yang memberdayakan seluruh potensi siswa agar siswa mampu melaksanakaan proses pembelajaran. Guru tidak menstransferkan pengetahuan yang telah dimilikinya, melainkan berusaha memberdayakan seluruh potensi dan sarana yang dapat membantu siswa untuk membantuk pengetahuannya sendiri. Guru bukan subjek pembelajaran, hanya sebagai fasilitator saja.

Temuan model penalaran deduktif terdapat pula di tulisan Ayuning Tyas W. Dengan judul "Penerapan Metode Contextual Teaching and Learning dalam Pembelajaran Menulis Puisi".

Guru adalah salah satu penentu keberhasilan proses belajar-mengajar. Seorang guru memiliki tanggung jawab langsung terhadap kemajuan peserta didik. Proses belajar-mengajar sudah selayaknya dilaksanakan sebaik mungkin. Di dalam kelas, guru diberikan wewenang penuh untuk mengatur segala sesuatu yang menunjang proses belajarmengajar, baik dari pendekatan, metode, teknik, maupun media pembelajaran.

Pembelajaran bahasa Indonesia memiliki empat keterampilan penting yang harus dikuasai oleh siswa. Empat keterampilan berbahasa tersebut terdiri dari: membaca,menyimak, menulis, dan berbicara. Keempat keterampilan tersebut saling mendukung satu dengan lainnya.

CTL merupakan suatu sistem yang menyeluruh. CTL terdiri dari bagian-bagian yang saling terhubung satu dengan lainnya. Jika bagian-bagian ini terjalin, makanakan menghasilkan pengaruh yang lebih besar daripada pengaruh yang dapat dihasilkan pada setiap bagiannya. Bagian-bagian CTL yang terpisah melibatkan proses-proses yang berbeda, yang ketika digunakan secara bersama-sama memampukan para siswa untuk menghasilkan makna.

Artikel ilmiah dengan judul "Upaya Meningkatkan Keterampilan Menulis Cerita Pendek dengan Metode Peta Pikiran (Mind Mapping) oleh Rahayu Saktiningsih juga ditemukan model penalaran deduktif. Hal ini tampak dalam paragraf berikut ini.

Peta pikiran (mind mapping) merupakan cara yang efektif dan efisien untuk memasukkan, menyimpan, dan mengeluarkan data dari atau ke otak. Metode ini dikategorikan dalam teknik kreatif karena pembuatan peta pikiran (mind mapping) ini membutuhkan pemanfaatan imajinasi dari si pembuatnya. 
Metode ini pertama kali diperkenalkan oleh Buzan pada awal 1970-an. Metode ini memungkinkann pembaca melihat keseluruhan gambar dan juga aspek individual dan mendorong siswa berpikir tidak hanya dalam hal informasi yang mereka inginkan untuk dikomunikasikan, namun juga dalam hubungan di antara ide. Metode ini sangat mudah untuk digunakan, karena menggunakan gambar-gambar yang lebih mudah dipahami oleh diri siswa yang membuatnya.

Demikian juga artikel ilmiah yang ditulis oleh Dyah Wuri Handayani yang berjudul "Penerapan Teknik KWL untuk Meningkatkan Komprehensi Membaca". Dalam artikel ini, model penalaran deduktif juga ditemukan pada paragraf berikut.

Salah satu upaya untuk meningkatkan komprehensi membaca siswa adalah dengan menggunakan teknik KWL. Teknik KWL sangat cocok untuk digunakan dalam pengajaran membaca karena berlandaskan pada pedoman strategi pengajaran membaca yang tepat. Dalam pedoman strategi pengajaran membaca tersebut, siswa harus melalui serangkaian tahapan-tahapan yang disebut proses membaca.

Teknik KWL juga mampu mengembangkan kemampuan membaca siswa dengan mengintegrasikan aspek membaca, menulis, berbicara, dan menyimak melalui serangkaian tahapan, yakni Know (apa yang diketahui), Want to know (apa yang ingin diketahui), dan Learned (apa yang sudah dipelajari). Teknik ini terbukti sesauai degan pedoman strategi pengajaran membaca dan sangat bermanfaat dalam meningkatkan keterampilan membaca komprehensif siswa, baik SMP maupun SMA.

Artikel ilmiah dengan judul "Pendidikan Inklusi dalam Novel Populer Laskar Pelangi" karya Zeni Triana terdapat model penalaran deduktif. Hal ini tampak di beberapa bagian artikel, di antaranya pada latar belakang masalah dan pembahasan.

Pendidikan merupakan faktor kebutuhan yang paling utama dalam kehidupan. Semua anak mempunyai hak yang sama untuk memperoleh pendidikan yang bermutu dan tidak didiskriminasi. Semua anak generasi penerus bangsa mempunyai kesempatan yang sama untuk memperoleh pendidikan. Baik mereka yang berstatus anak normal, maupun anak yang terbelakang mentalnya. Selama ini, anak yang terbelakang mentalnya hanya dipandang sebelah mata saja, mereka mendapatkan fasilitas yang pas-pasan dan hanya bisa diterima di SLB atau sekolah terbuka. Sementara itu, mereka dengan status anak normal mendapatkan fasilitas yang sangat lengkap dengan pilihan sekolah negeri di segala penjuru.

Pendidikan inklusi didasari semangat terbuka untuk merangkul semua kalangan dalam pendidikan. Pendidikan inklusi merupakan implementasi pendidikan yang berwawasan multikural yang dapat membantu peserta didik mengerti, menerima, serta menghargai orang lain yang berbeda suku, budaya, nilai, kepribadian, dan keberfungsian fisik maupun psikologis.

Di artikel yang lain dengan judul "Metode Snowball Throwing untuk Menumbuhkan Keberanian Siswa dalam Berpendapat" oleh Dian Desi R. juga ditemukan model penalaran deduktif. Pola ini tampak di beberapa bagian artikel seperti tampak di bawah ini.

Melalui metode Snowball Throwing, siswa diajak untuk mencari informasi materi secara umum, membentuk kelompok, membentuk ketua (patih) dan diberi tugas membahas materi tertentu dikelompok, bekerja secara kelompok. Selanjutnya, tiap kelompok menuliskan pertanyaan atau tanggapan dan diberikan kepada kelompok lain, kelompok lain menjawab secara bergantian, untuk diambil suatu kesimpulan dari hasil jawaban kelompok terhadap pertanyaan atau menanggapi pendapat yang telah diterimanya. Dalam metode Snowball Throwing, guru berusaha memberikan kesempatan kepada siswa untuk mengembangkan keterampilan menyimpulkan isi berita atau informasi yang mereka peroleh dalam konteks nyata dan situasi yang kompleks. Guru juga memberikan pengalaman kepada siswa melalui pembelajaran terpadu, dengan menggunakan proses yang saling berkaitan 
dalam situasi dan konteks komunikasi alamiah baik sosial, sains, hitungan dan lingkungan pergaulan. Melalui prinsip-prinsip pemakaian metode pengajaran semacam itu, pendekatan dalam pembelajaran mampu meningkatkan keaktifan belajar saat proses pembelajaran di kelas. Situasi akan lebih menarik dan menggugah rasa keingintahuan lebih dalam terhadap materi yang sedang disampaikan, karena secara tidak langsung antara siswa yang satu dengan yang lain bertukar pikiran dengan saling menjawab pertanyaan yang diterimanya, maupun menanggapi opini atau pendapat teman yang lain. Padahal, tiap otak siswa pasti mempunyai jawaban atau pendapat yang berbeda-beda, yang menyebabkan timbulnya variasi jawaban atau pendapat antara satu sama lain.

\section{Model Penalaran Induktif}

Di samping model penalaran deduktif, artikel di atas juga memiliki model penalaran induktif, di antaranya sebagai berikut.

Jadi, metode ini baik digunakan dalam kelas yang siswanya cenderung diam. Di dalam metode pembelajaran snowball throwing, strategi memperoleh dan pendalaman pengetahuan lebih diutamakan dibandingkan seberapa banyak siswa memperoleh dan mengingat pengetahuan tersebut. Penerapan metode snowball throwing ini juga memerlukan keterampilan seorang guru dalam menguasai kondisi kelas. Penerapan metode ini cenderung membuat siswa agak sulit diatur, karena proses pelaksanaannya berkelompok, dimana siswa akan lebih ribut jika bersama teman-teman sebayanya. Metode snowball throwing ini membuat siswa lebih berani mengemukakan pendapatnya, karena menggunakan cooperative learning dan proses metode yang menarik dan fun untuk dilaksanakan.

Model penalaran induktif juga ditemukan dalam tulisan Vita Indriana Susanti dengan judul "Penerapan Media Gambar Berseri dalam Pembelajaran Menulis Cerpen"

Kemampuan menulis cerpen siswa masih rendah. Guru sebagai penyampai materi tidak dapat memberikan stimulus yang baik kepada siswa. Media pembelajaran yang dipakai oleh guru pun tidak menarik perhatian siswa.Perlu adanya media dalam pembelajaran, agar siswa mampu menulis cerpen dengan baik. Sehingga siswa apresiatif terhadap pembelajaran menulis cerpen. Media pembelajaran dapat berupa media gambar berseri. Media gambar berseri berperan dalam pembelajaran menulis cerpen. Artikel ini akan mengulas mengenai apa itu media gambar berseri beserta penerapannya dalam pembelajaran menulis cerpen.

"Pendidikan Moral pada Anak Melalui Fabel" artikel yang ditulis oleh Rahma Nur Fitriana juga ditemukan model penalaran induktif.

Dalam perkembangannya, anak tidak dapat mempelajari sendiri nilai moral yang berlaku dalam masyarakat. Dengan mengambil sudut pandang orang lain, akan membantu anak memahami apa yang benar dan apa yang salah. Oleh karena itu, diperlukan pengajaran mengenai moral kepada anak dengan orang tua sebagai pihak yang memiliki peranan tertinggi dalam mengajarkan pendidikan moral tersebut. Pengajaran moral pada anak penting dilakukan, karena pada masa itu mereka menganggap orang tua sebagai pihak serba tahu yang akan dipatuhi semua perintahnya. Dalam hal ini, yang paling utama adalah mengenai kecerdasan orang tua dalam menyampaikan pendidikan moral. Orang tua harus mampu menanamkan nilai moral pada anak dengan cara yang menarik, sehingga dengan mudah anak dapat menyerap dan menanamkan pada diri sendiri moral tersebut.

Model penalaran berdasarkan arah atau alur dalam artikel ilmiah mahasiswa lebih dominan model alur deduktif. Di setiap artikel ilmiah mahasiswa terdapat model tersebut, bahkan lebih dari satu penalaran deduktif untuk setiap tulisan mahasiswa. Model induktif juga ditemukan dalam artikel ilmiah mahasiswa. Namun jumlahnya tidak dominan seperti model penalaran deduktif. Model penalaran deduktif menjadi pilihan bagi setiap mahasiswa Program Studi Pendidikan Bahasa dan Sastra In- 
donesia dalam menyampaikan gagasan ilmiah. Hal ini dapat diinterpretasikan bahwa model penalaran deduktif adalah model yang mudah dipahami, baik oleh penulis maupun pembaca. Model penalaran deduktif bertolak dari suatu pernyataan/umum berupa kaidah, peraturan, teori, atau pernyataan umum lainnya. Selanjutnya, pernyataan itu dikembangkan menjadi rincian-rincan yang bersifat khusus.

\section{Model Penalaran Berdasarkan Urutan Pengembangan Paragraf}

Model penalaran tidak dapat dipisahkan dari pola pengembangan paragraf. Dari hasil penelitian ditemukan beberapa model berdasarkan urutan pengembangan paragraf dalam setiap arttikel ilmiah mahasiswa, di antaranya sebagai berikut.

\section{a. Model Urutan Waktu atau Kronologis}

Model ini terdapat dalam artikel yang berjudul "Pendidikan Inklusi dala Novel Populer Laskar Pelangi"

Saat masuk kelas 1 SD, umur Harun sudah 15 tahun dan tercatat sebagai murid yang mendaftar paling akhir. Meski terbelakang mental, kehadiran harun disambut bagaikan pahlawan. Harun berjasa menyelamatkan kelangsungan pendidikan di SD Muhammadiyah Belitong. Pengawas dari Depdikbud Sumatera Selatan sudah memperingatkan, kalau tidak mampu mencari murid minimal sepuluh orang, sekolah dasar paling tua di Belitong itu akan ditutup. Tahun sebelumnya, sekolah dasar tersebut masih merekrut 11 anak. Tapi tahun itu, saat anak-anak laskar pelangi masuk, para guru dan orang tua murid sempat panik, hingga deadline pukul 11.00, murid yang terdaftar baru sembilan orang.

Dalam situasi kritis itu, Harun datang, didampingi ibunya, mendaftar sebagai murid ke sepuluh. Selamatlah SD Muhammadiyah dari penutupan. Dipilhnya SD tersebut oleh orang tua Harun lebih banyak karena faktor kebetulan. Sekolah Luar Biasa (SLB), kebetulan, tidak tersedia di Pulau Belitong. Adanya di pulau Bangka, pulau yang terpisah Seolat Gaspar, di sebelah Barat Belitong. Selain jauh orang tua Harun tak punya cukup ongkos sekolah kesana. Alasan berikutnya, dan ini cukup menggelikan, menurut ibunya Harun, "lagi pula lebih baik kutitipkan di sekolah ini daripada di rumah dia hanya mengejar-ejar anak-anak ayamku".

Dalam artikel yang lain juga ditemukan urutan kronologis, artikel tersebut berjudul "Pembelajaran Bahasa Mandarin di Sekolah Dasar Yogyakarta" oleh Peng Zhi Lien.

Sudah sejak abad ke-19, sekolompok orang asal China yang anak-anaknya lahir di Indonesia mendirikan sekolah yang bertujuan memberikan pendidikan bahasa dan kebudayaan China serta menumbuhkan rasa persatuan orang-orang Tionghoa. Seiring berjalan waktu, sekolah-sekolah Tionghoa di Indonesia semakin berkembang pada masa pemerintahan Presiden Soeharto. Semua sekolah Tionghoa di Indonesia secara paksa. Tidak hanya itu, huruf Tionghoa dilarang digunakan di tempat umum. Semua buku percetakan juga tidak boleh dicetak menggunakan bahasa mandarin. Setelah Presiden Soeharto dilengserkan kekuasaannya, bahasa Mandarin mulai berkembang di seluruh wilayah Indonesia.

Kedua temuan di atas dikembangkan secara kronologis, artinya berdasarkan urutan waktu. Urutan kronologis dalam tulisan secara eksplisit dinyatakan dengan kata-kata seperti saat, tahun sebelumnya, tahun itu, sejak abad, dan seiring berjalannya waktu.

\section{b. Model Urutan Kepentingan}

Model urutan kepentingan juga ditemukan di beberapa artikel ilmiah mahasiswa. Hal ini terkait dengan urutan kepentingan gagasan yang dikemukakan. Arah pembicaraannya adalah dari yang paling penting sampaai kepada yang paling tidak penting, dan sebaliknya. Temuan dalam artikel ilmiah mahasiswa terkait urutan kepentingan gagasan yang dikemukakan pada artikel yang berjudul "Metode Snowball Throwing untuk Menumbuhkan Keberanian Siswa dalam Berpendapat" sebagai berikut.

Metode throwing menggunakan langkah-langkah sebagai berikut: 
1. guru membagi siswa ke dalam beberapa kelompok, dengan nama-nama yang unik yang bisa teknik ini menarik misalnya, nama kerajaan,

2. setiap kerajaan mencalonkan salah satu temannya untuk menjadi utusan kerajaan/ patih,

3. para patih meninggalkan ruang kelas bersama-sama untuk menerima materi di tempat lain, selain kelas. Guru menyampaikan materi yang akan disajikan,

4. sementara itu, anggota kerajaan/kelompok yang lain menunggu sang patih dari tugas yang diembannya,

5. ketika sedang menerima materi, para patih diharapkan membuat catatan sehingga, mereka akan mengulang materi yang akan disampaikan kepada anggota kerajaan yang lain,

6. para patih kembali ke kelas dan menjelaskan materi yang didapat kepada anggota kerajaan/kelompok,

7. kemudian, para anggota menulis pertanyaan atau tanggapan tentang materi yang disampaikan patih, pada selembar kertas yang digulung berbentuk bola salju,

8. setelah itu, siswa saling melempar bola salju ke siswa yang lain,

9. siswa yang mendapat lemparan bola salju itu, kemudian menjawab pertanyaan atau memberikan pendapatnya dengan maju berbicara di depan kelas.

Temuan model ini juga ditemukan di artikel yang berjudul "Pendidikan Moral pada Anak melalui Fabel".

Menurut Nurgiyantoro (2005: 56), kemungkinan implikasi bagi seleksi bacaan sastra anak antara lain dapat dikemukakan sebagai berikut.

1. Memahami dengan baik karakteristik perkembangan moral anak tiap tahap (berdasarkan teori perkembangan moral Kohlberg), kemudian orang tua memilih bacaan yang sesuai untuk anak.

2. Memilih bacaan yang mengandung dan menawarkan unsur moral, alasan pemilihan moral tertentu oleh tokoh anak, atau yang mengandung nasihat-nasihat tentang moral sebagai contoh untuk bertingkah laku dalam kehidupan sehari-hari di masyarakat.

\section{Model Penalaran Berdasarkan Isi Kara- ngan}

Isi karangan dapat menampilkan fakta berupa benda, kejadian, gejala, siafat, atau ciri sesuatu. Model penalaran berdasarkan isi karangan yang ditemukan dalam artikel ilmiah mahasiswa Program Studi Pendidikan Bahasa dan sastra Indonesia akan diuraikan berikut ini.

\section{a. Generalisasi dan Spesifikasi}

Generalisasi adalah pernyataan yang berlaku umum untuk semua atau sebagian besar gejala yang diamati. Pengembangan karangan generalisasi ditunjang oleh fakta-fakta, contohcontoh, data statistik, dan sebaginya yang merupakan spesifikasi atau ciri khusus sebagai penjelasan lebih lanjut. Temuan dalam artikel ilmiah dapat dilihat pada artikel yang berjudul "Membangun Karakter Siswa yang Berbasis Kearifan Lokal Yogyakrta" oleh Aluwisih Sang Saparti.

Berdasarkan uraian di atas dapat dikemukakan bahwa membangun pendidikan karakter di sekolah melalui kearifan lokal mengandung nilai-nilai yang relevan dan berguna bagi pendidikan. Oleh karena itu pendidikan karakter berbasis kearifan lokal dapat dilakukan dengan merevitalisasi budaya lokal. Untuk mewujudkan pendidikan karakter di sekolah berbasis kearifan lokal memerlukan adanya pengertian, pemahaman, kesadaran, kerja sama, dan partisipasi seluruh elemen warga belajar.

Temuan model generalisasi pada artikel ilmiah yang berjudul "Pengembangan Karakter Siswa SMP/SMA Melalui Strategi Pembelajaran Berbasis Masalah (SPBM)".

Berdasarkan UU tentang Sistem Pendidikan Nasional, terkait fungsi dan tujuan, maka pedidikan berbasis karakter adalah langkah yang tepat sebagai tindak penyelesaian problematika atau perilaku negatif yang dilakukan anak sekolah (remaja). Pengembangan karakter bagi siswa SMP/ SMA dapat melalui kombinasi Strategi Pembelajaran Berbasis Masalah (SPBM) dengan tiga langkah dan sebelas prinsip pengembangan karakter. Pengembangan tersebut meliputi tahap menemukan dan menyadari masalah, mengumpulkan data; 
diskusi dan merumuskan masalah; menyusun hipotesis; menentukan solusi; dan menarik kesimpulan.

\section{b. Klasifikasi}

Klasifikasi adalah pengelompokan fakta-fakta berdasarkan kriteria tertentu. Dalam pengembangan karangan, klasifikasi dapat merupakan topik karangan atau paragraf, dapat pula dipergunakan sebagai dasar untuk menentukan urutan pembicaraan. Berikut temuan model klasifikasi dalam artikel ilmiah mahasiswa. Artikel berjudul " Pendidikan Moral pada Anak melalui Fabel"

Berikut ini ketiga tingkat perkembangan moral yang masing-masing tingkat memuat pula dua tahap perkembangan.

1. Tingkat Prakonvensional

Dalam tingkatan prakonvensional ini, dapat dibedakan adanya dua tahap, antara lain.

a. Tahap punishment and obedience orientation

Dalam tingkat ini, anak cenderung menghindari hukuman, maka anak akan terlihat sangat patuh dan berbuat baik untuk menghindari hukuman.

b. Tahap instrumental-relativist atau hedonistics orientation

Dalam tahap ini, anak mulai dapat membedakan akibat fisik. Di sini, pemikiran anak mengenai benar atau salah belum jelas, tergantung apakah itu memuaskan keinginannya atau tidak.

2. Tingkat Konvensional

Tingkat konvensional ini mencakup dua tahap perkembangan moral yang lebih tinggi dari tingkat sebelumnya. Kedua tahap tersebut antara lain.

a. Tahap interpersonal concordance atau good-boy/nicegirl orientation

Dalam tingkat ini, anak lebih memfokuskan diri pada apa yang diharapkan oleh orang lain (keluarga atau kelompok lain seperti sekolah). Anak akan menaruh perhatiannya pada harapan-harapan sosial yang ada di sekitarnya. Mereka melakukan suatu tindakan tertentu karena menganggap perilaku itu baik untuk keluarga atau kelompoknya. Pada tahap ini, anak sudah mulai tidak egosentris.
Anak tidak lagi mendahulukan egonya sendiri, tetapi mulai memperhatikan apa yang diharapkan oleh orang lain tentang dirinya.

b. Tahap law and order orientation

Dalam tahap ini, anak menganggap nilai moral baik atau buruk merupakan suatu kewajiban dengan tujuan menjaga keseimbangan dan ketertiban masyarakat.

3. Tingkat Pascakonvensional

a. Tahap social-contract, legalistic orientation

Dalam tahapan ini, anak akan menentukan apakah aturan tersebut sesuai dengan moral atau tidak, jika sesuai ia akan mengikuti aturan tersebut dan sebaliknya.

b. Tahap orientation of universal ethical principles

Dalam tahap terakhir ini, penalaran moral sudah berdasarkan kata hati. Tindakan dalam tahapan ini sebagai keputusan kata hatinya.

\section{c. Perbandingan dan Pertentangan}

Perbandingan dan pertentangan merupakan dua hal yang berbeda tetapi erat hubungannya. Keduannya sering kali terdapat daalam satu karangan. Perbandingan adalah pernyataan mengenai persamaan dan kemiripan sedangkan pertentangan adalah pernyataan tentang perbedaan. Berikut ini akan disajikan temuan model perbandingan dan pertentangan dalam artikel ilmiah mahasiswa. Temuan pola ini terdapat dalam artikel yang berjudul "Pentingnya Memilih Media yang Tepat dalam Pembelajaran Bahasa Indonesia".

Pada kenyataannya, penggunaan bahasa Indonesia yang baik dan benar kini sulit ditemui, baik di kalangan pelajar, masyarakat biasa, maupun pejabat. Orang tua saat ini cenderung mengarahkan anaknya untuk mengembangkan bahasa asing, bahkan tidak jarang orang yang mencemooh seorang anak yang memilih jurusan bahasa Indonesia. Kenyataan lainnya, orang erasa kurang hebat kalau tidak mencampuradukkan bahasa asing ke dalam bahasa Indonesia dalam percakapan kesehariannya. Mereka tidak menyadari hal tersebut akan menjadikan 
bahasa Indonesia menjadi buruk untuk digunakan dalam kehidupan yang sudah serba modern seperti sekarang ini.

Temuan model perbandingan juga terdapat dalam artikel yang berjudul "Inovasi Pembelajaran Bahasa Indonesia untuk Siswa SMA melalui Pendekatan Konstruktivisme".

Pendekatan pembelajaran behaviorisme saaat ini disamaartikan dengan pendekatan pembelajaran tradisional. Pendekatan ini memiliki beberapa kelebihan dan kekurangan ketika diterapkan dalam proses pembelajaran. Kelebihan dari pendekatan ini iaah adanya respon yang mampu mendorong siswa untuk memberikan tanggapan. Pembelajaran seperti ini cocok diterapkan untuk keterampilan yang membutuhkan pembiasaan. Melalui pendekatan ini memungkinkan pemberian rangsangan yang berbeda-beda secara berulang-ulang hingga siswa mapu menanggapi rangsang tersebut sesuai penilaian yang diharapkan. Terkadang dalam pendekatan pembelajaran behaviorisme menganjurkan adanya penghargaan langsung maupun hukuman. Kedua hal tersebut dapat mempengaruhi tingkah laku siswa selama menerima pelajaran. Pendekatan behaviorisme memiliki banyak kekurangan. Pendekatan ini lebih menekankan guru sebagai pusat pembelajaran. Sementara itu, siswa cenderung pasif dan tingkah laku siswa selalu teramati. Siswa hanya mendengarkan penjelasan guru kemudian menghafal apa yang telah mereka lihat dan dengar. Pendekatan behaviorisme mengacu pada stimulus eksternal seperti motivasi dari guru sehingga kebutuhan belajar siswa bukan dari kesadaran secara pribadi. Aselain itu, penggunaan hukuman dalam kebiatan pembeajaran tidak selalu dapat membangun karakter siswa menjadi lebih baik. Aakan tetapi, hal tersebut cenderung berdampak buruk bagi psikologis siswa.

\section{d. Hubungan Sebab Akibat}

Hubungan sebab akibat merupakan hubungan ketergantungan antara dua hal atau lebih. Artinya, suatu akibat hanya akan terjadi bila ada sebabnya. Dengan kata lain, sebab sela- lu mendahului akibat. Oleh karena itu, hubungan sebab akibat menampakkan persamaan dengan urutan waktu/kronologis. Namun tidak semua urutan kronologis merupakan hubungan sebab akibat. Berikut ini temuan hubungan sebab akibat alam artikel ilmiah mahasiswa. Artikel berjudul "Penerapan Metode Contextual Teaching and Learning dalam Pembalajaran Menulis Puisi".

Oleh karena minat siswa untuk menulis puisi masih rendah, maka perlu dicari solusinya. Salah satu penyebab utamanya adalah media yang digunakan oleh guru dirasa kurang menarik bagi siswa. Selama ini guru hanya menggunakan media yang monoton. Bahkan terkadang, guru hanya menggunakan media yang apa adanya. Pemilihan media hendaknya disesuaikan dengan materi yang akan diajarkan. Seperti halnya media yang digunakan dalam proses pembelajaran puisi, diharapkan dapat menarik perhatian siswa, sehingga materimateri yang diajarkan dapat tersampaikan dengan baik. Dengan demikian, siswa juga dapat lebih mudah untuk memahami materi yang sedang diajarkan.

\section{SIMPULAN}

Berdasarkan hasil temuan dan pembahasan di atas dapat disimpulkan bahwa model penalaran yang terdapat dalam artikel ilmiah mahasiswa Program Studi Pendidikan Bahasa dan Sastra Indonesia, Fakultas Bahasa dan Seni, Universitas Negeri Yogyakarta dapat diklasifikasikan berdasarkan arah atau alur penalaran yakni penalaran deduktif dan penalaran induktif. Model penalaran deduktif bersifat dominan, artinya di setiap artikel ilmiah mahasiswa terdapat model penalaran tersebut, bahkan model tersebut beberapa kali muncul pada setiap artikel ilmiah mahasiswa. Model penalaran deduktif bertolak dari pernyataan umum, kemudian dirinci dalam penjelasan atau rincian-rincian yang lebih khusus. Hal ini akan memudahkan pemahaman antara penulis dan pembaca dalam berkomunikasi tidak langsung.

Model penalaran juga dapat diklasifikasikan berdasarkan urutan pengembangan paragraf. Temuan dalam penelitian ini antara lain model urutan waktu atau kronologis dan 
model urutan kepentingan. Model urutan waktu paling banyak muncul dalam pendahuluan, sedangkan model urutan kepentingan muncul pada kajian teori dan pembahasan. Selain itu, model penalaran juga dapat diklasifikasikan berdasarkan isi karangan. Dalam penelitian ini ditemukan model generalisasi dan spesifikasi, klasifikasi, perbandingan dan pertentangan, dan hubungan sebab akibat.

\section{DAFTAR PUSTAKA}

Akhadiah, Sabarti, Maidar G. Arsjad, dan Sakura H. Ridwan. 1996. Pembinaan Kemampuan Menulis Bahasa Indonesia. Jakarta: Erlangga.
Budiharso, Teguh. 2009. Panduan Lengkap Penulisan Karya Ilmiah. Yogyakarta: Venus.

Rahardi, R. Kunjana. 2009. Bahasa Indonesia untuk Perguruan Tinggi. Jakarta: Erlangga.

2009. Penyuntingan $B a-$ hasa Indonesia untuk Karang-Mengarang. Jakarta: Erlangga.

Zuchdi, Darmiyati. 1993. Panduan Penelitian Analisis Konten. Yogyakarta: Lembaga Penelitian IKIP Yogyakarta. 